\title{
Meta-Analysis the Effect of Nicotine Replacement Therapy on the Successful Smoking Cessation
}

\author{
Lina Eta Safitri'), Agus Kristiyanto²), Bhisma Murti1) \\ 1)Masters Program in Public Health, Universitas Sebelas Maret \\ 2)Faculty of Sports, Universitas Sebelas Maret
}

\section{ABSTRACT}

Background: About $23 \%$ of the world's population smokes, which includes $32 \%$ of men with the highest prevalence coming from Indonesia and $7 \%$ are women. East Asia and Southeast Asia have the highest smoking prevalence in the world at around $45 \%$, while in Indonesia, the problem of smoking is a serious threat due to the increasing prevalence of smoking at 18 years of age from $7.2 \%$ to $9.1 \%$. This study aims to analyze the magnitude of the effect of using NRT on the success of smoking cessation based on a number of previous similar studies.

Subjects and Method: This research is a systematic review and meta-analysis carried out by following the PRISMA flow diagram. The process of searching for articles through a journal database which includes: Google Scholar, PubMed, and Science Direct by selecting articles published in 2011-2020. Keywords used include: "nicotine replacement therapy" AND "smoker" OR "smoking" AND "smoking cessation". The inclusion criteria were a full paper article with an Cite this as: observational study design, English and Indonesian, and analyzed using multivariate analysis with adjusted odds ratio. Articles that meet the requirements were analyzed using the Revman 5.3 application.

Results: Nine articles were reviewed in this study with a cohort study design. A metaanalysis of nine cohort studies showed that use of nicotine replacement therapy was 1.42-fold increased smoking cessation success compared to placebo (aOR 1.42; 95\% CI 1.14 to $1.76 ; \mathrm{p}$ $<0.002$ ).

Conclusion: Nicotine replacement therapy improves smoking cessation success.

Keywords: nicotine replacement therapy, smoking cessation

\section{Correspondence:}

Lina Eta Safitri. Masters Program in Public Health, Universitas Sebelas Maret, Jl. Ir. Sutami 36A, Surakarta 57126, Central Java. Email: Linaetasafitri_96@student.uns.ac.id.

Safitri LE, Kristiyanto A, Murti B (2021). Meta-Analysis the Effect of Nicotine Replacement Therapy on the Successful Smoking Cessation. J Epidemiol Public Health. 06(01): 21-32. https://doi.org/10.26911/jepublichealth.2021.06.01.03.

cc (i)(2) Journal of Epidemiology and Public Healthis licensed under a Creative Commons EY NG SA Attribution-NonCommercial-ShareAlike 4.0 International License.

\section{BACKGROUND}

About $23 \%$ of the world's population smokes. Includes $32 \%$ male with the highest prevalence coming from Indonesia and 7\% being female. East Asia and Southeast Asia have the highest smoking prevalence in the world at around $45 \%$, while in Indonesia, the problem of smoking is a serious threat due to the increasing prevalence of smoking at 18 years of age from $7.2 \%$ to
9.1\% (Adam et al., 2020; Ministry of Health, 2019).

Smoking usually begins with trial and error behavior as a teenager, many factors support this behavior. Research in Riau and Bantul states that smoking behavior in male adolescents increases along with high family income, high pocket money, the influence of advertising media on cigarettes, smoking behavior in parents, lack of 
knowledge, lack of parental support, peer influence, and the perception of low cigarette prices (Islami et al., 2019; Arifianti et al., 2019)

In 2015, Indonesia contributed more than 130,000 deaths due to tobacco consumption each year (Ministry of Health, 2019). Smoking is the leading cause of preventable death worldwide. Smoking is also a major contributor to morbidity, reducing fertility, coronary heart disease, diabetes and countless other health complications (Martin at al., 2018).

According to WHO (2020) tobacco kills more than 8 million people worldwide each year. More than 7 million of these deaths were attributable to direct tobacco use and about 1.2 million to exposure to secondhand smoke. In addition, smoking is known to be a risk factor for various respiratory infections and increases the severity of respiratory tract diseases. A review of research conducted by public health experts conducted by WHO on April 29, 2020 show that smokers were more likely to suffer from severe Covid-19 than nonsmokers.

Most smokers are aware that smoking is a dangerous health behavior and in the end they have a desire to quit smoking, but trying to quit smoking is challenging and some of them end up in failure, despite many studies which claim that some smoking cessation methods are effective but the rate of quitting smoking remains low, the addictive nature of smoking can be attributed to the pharmacological effects of nicotine where nicotine can affect the social interaction function of smokers, people who smoke have higher anxiety disorders compared to nonsmokers, people who smoke have barriers to memory fear in the context of self-safety, this is caused by a nicotinergic or dopaminergic mechanism. Where this can be an inhibiting reason in efforts to quit smoking (Islami et al., 2019; Arifianti et al., 2019)

Tobacco smoking has a correlation with an increased risk of developing 17 types of cancer in humans. There are about 6o known cancer-causing molecules called carcinogens in tobacco smoke (Linda et al., 2015).

Meta-analysis is an epidemiological design that aims to systematically study and combine the results of quantitative estimates from a number of previous studies that answer the same research problems and can be combined. Many primary studies have conducted the effect of NRT on smoking cessation success.

Further analysis is needed to arrive at a convincing conclusion. Based on this background, researchers are interested in conducting a systematic review and metaanalysis of "The Effect of Nicotine Replacement Therapy on the Success of Quitting Smoking".

\section{SUBJECTS AND METHOD}

\section{Study Design}

This was a systematic review and metaanalysis. The articles used in this study were obtained from several databases including Pub-Med, Google Scholar, and ScienceDirect. The keywords include: "Nicotine Replacement Therapy" OR NicotineReplacement "AND tobacco OR smoke OR smoked OR smoker AND" smoking cessation".

\section{Inclusion Criteria}

The inclusion criteria for articles that can be reviewed are full paper articles with observational study designs, articles using English and Indonesian, multivariate analysis used with adjusted odds ratios, interventions given by NRT research subjects are adult smokers, the outcome is the success of quitting smoking. 


\section{Exclusion Criteria}

Articles published in this study are articles that have been meta-analysis, articles published in addition to using English and Indonesian, and articles with results that are not adjusted Odds Ratio.

\section{Operational Definition}

The article search was carried out by considering the eligibility criteria defined using the PICO model. The population in the study was adult smokers with intervention in the form of nicotine replacement therapy, comparison with placebo and success outcomes for quitting smoking.

Nicotine replacement therapy is the administration of nicotine therapy to quit smoking in adult smokers in the form of a nicotine patch which is done for 12 weeks.

The success of quitting smoking is the smoker's ability not to smoke after doing nicotine therapy to quit smoking.

\section{Data Analysis}

Data processing was carried out by the Review Manager (RevMan 5.3) by calculating the effect size and heterogeneity to determine the research model that was combined and formed the final result of the meta-analysis.

\section{RESULTS}

The process of searching for articles by searching through the database according to PRISMA flow diagrams. The initial search process in the database yielded 1213 articles and there were the addition of 50 articles identified from other searches, then through the process of deleting multiple articles as many as 281 articles with 982 filtered articles of which were eligible for further full text review can be seen in Figure 1.

Research related to the effect of nicotine replacement therapy on the success of smoking cessation consists of 9 articles from 6 North American continents, 2 from Europe and 1 from Australia.

The interpretation of the results from the meta-analysis process can be seen through the forest plot. Figure 3 shows that the use of NRT can increase the success of smoking cessation. The results of a metaanalysis in a retrospective cohort study showed that the use of NRT increased smoking cessation success by 1.42 times compared to placebo and was statistically significant $(\mathrm{aOR}=1.42 ; 95 \% \mathrm{CI}=1.14$ to 1.17; $\mathrm{p}=0.002$ ). The heterogeneity of the research data shows I2 $=95 \%$ so that the distribution of the data is stated to be heterogeneous (random effect model)

Based on Figure 4, it shows that there is a publication bias which is characterized by asymmetry of the right and left plots where 6 plots are on the right and 3 plots are on the left. Bias also occurs from an imbalance between the distances between studies on both the right and left of the funnel plot. 
Safitri et al./ Nicotine Replacement Therapy on the Successful Smoking Cessation

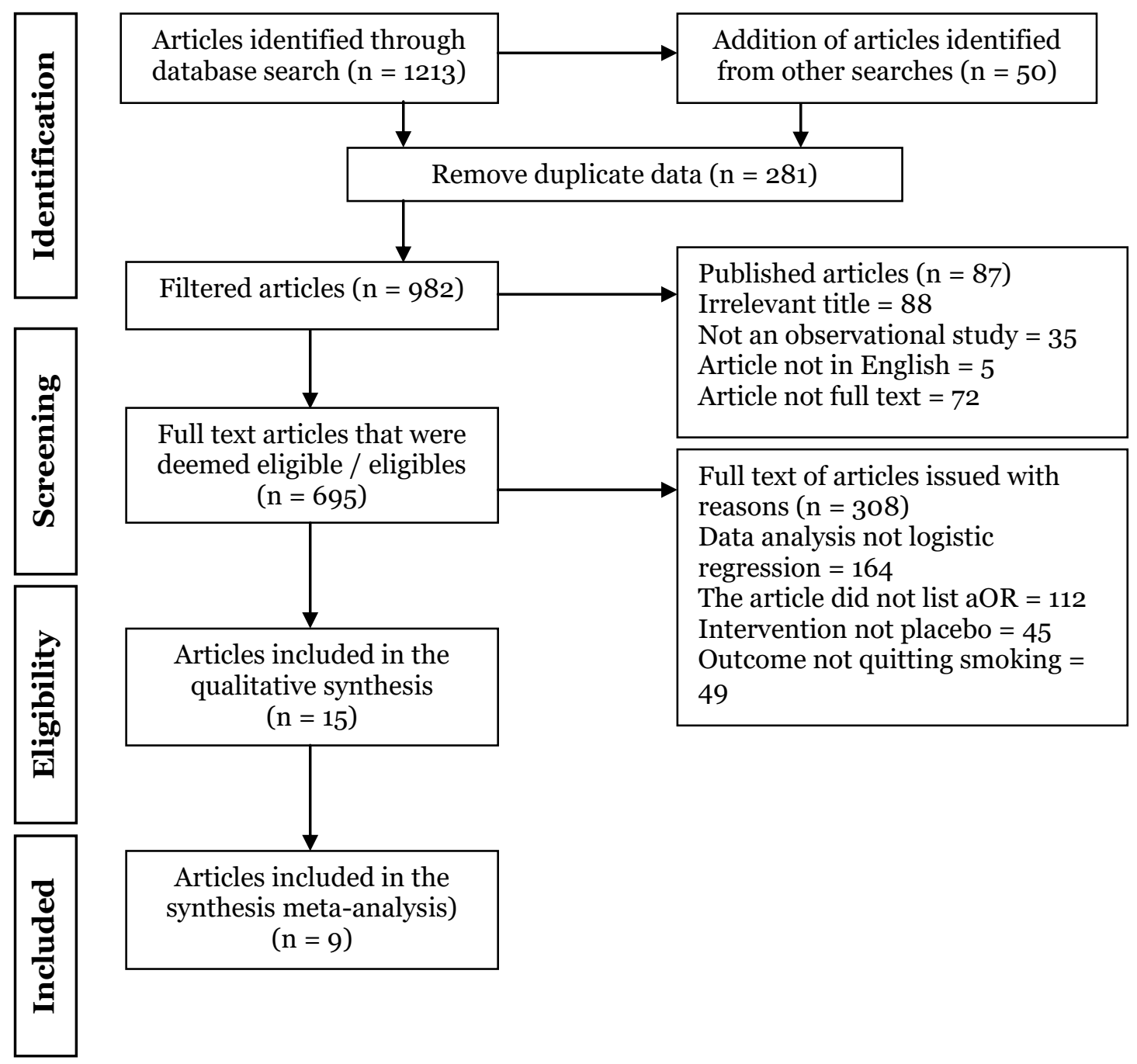

Figure 1. PRISMA flow diagram

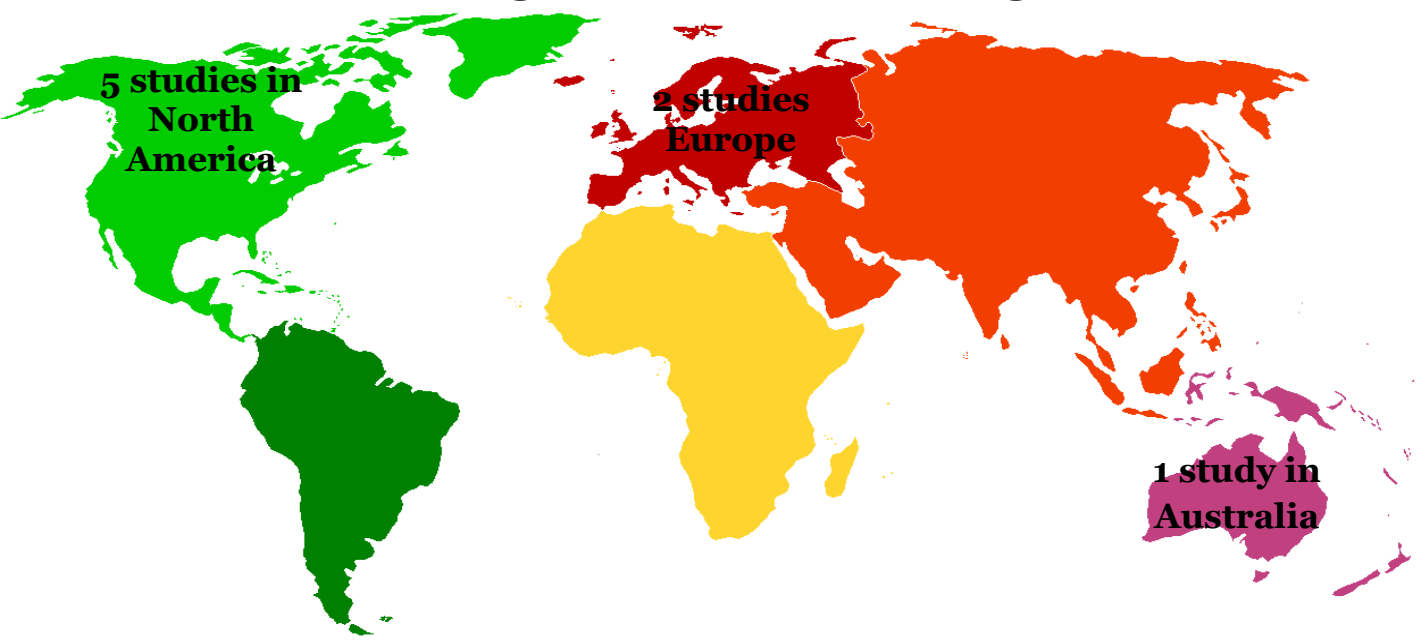

Figure 2. Map of research areas on the effect of nicotine replacement therapy on smoking cessation success

Source: https://freepik.com/premium-vector/multicolor-map-continents 
Table 1. Assessment of Research Quality using Critical Appraisal Questions for Cohort Study

\begin{tabular}{|c|c|c|c|c|c|}
\hline Checklist Questions & $\begin{array}{l}\text { Beard et al. } \\
\text { (2013) }\end{array}$ & $\begin{array}{l}\text { Anthenelli et } \\
\text { al. (2016) }\end{array}$ & $\begin{array}{l}\text { Hollands } \\
\text { et al. (2013) }\end{array}$ & $\begin{array}{c}\text { Japuntich et al. } \\
\text { (2014) }\end{array}$ & $\begin{array}{c}\text { Lerman } \\
\text { et al. (2015) }\end{array}$ \\
\hline Does this research address clearly focused issues? & 1 & 1 & 1 & 1 & 1 \\
\hline $\begin{array}{l}\text { Is the cohort research method appropriate for answering } \\
\text { research questions? }\end{array}$ & 1 & 1 & 1 & 1 & 1 \\
\hline $\begin{array}{l}\text { Are there enough subjects to determine that the findings } \\
\text { were not by chance? }\end{array}$ & 1 & 1 & 1 & 1 & 1 \\
\hline $\begin{array}{l}\text { Is the selection of cohorts based on objective and } \\
\text { validated criteria? }\end{array}$ & 1 & 1 & 1 & 1 & 1 \\
\hline Is the cohort representative of the defined population? & 1 & 1 & 1 & 1 & 1 \\
\hline Was there sufficient follow-up? & 1 & 1 & 1 & 1 & 1 \\
\hline Are objective and unbiased results criteria used? & 1 & 1 & 1 & 1 & 1 \\
\hline $\begin{array}{l}\text { Is the nicotine patch intervention measurement method } \\
\text { validated? }\end{array}$ & 1 & 1 & 1 & 1 & 1 \\
\hline Is the effect size practically relevant? & 1 & 1 & 1 & 1 & 1 \\
\hline Was there any conviction intervention provided? & 1 & 1 & 1 & 1 & 1 \\
\hline Have you taken the confounding factor into account? & 1 & 1 & 1 & 1 & 1 \\
\hline Do the results apply to your research? & 1 & 1 & 1 & 1 & 1 \\
\hline Total & 12 & 12 & 12 & 12 & 12 \\
\hline
\end{tabular}

Answer: $1=$ Yes, $\mathrm{O}=\mathrm{No}$

Table 2. Assessment of Research Quality using Critical Appraisal Questions for Cohort Study

\begin{tabular}{|c|c|c|c|c|}
\hline Checklist Questions & $\begin{array}{c}\text { Lerman } \\
\text { et al. (2015) }\end{array}$ & $\begin{array}{c}\text { Piper } \\
\text { et al. (2011) }\end{array}$ & $\begin{array}{c}\text { Kusnir et al. } \\
(2017)\end{array}$ & $\begin{array}{c}\text { West et al. } \\
(2017)\end{array}$ \\
\hline Does this research address clearly focused issues? & 1 & 1 & 1 & 1 \\
\hline Is the cohort research method appropriate for answering research questions? & 1 & 1 & 1 & 1 \\
\hline Are there enough subjects to determine that the findings were not by chance? & 1 & 1 & 1 & 1 \\
\hline Is the selection of cohorts based on objective and validated criteria? & 1 & 1 & 1 & 1 \\
\hline Is the cohort representative of the defined population? & 1 & 1 & 1 & 1 \\
\hline Was there sufficient follow-up? & o & 1 & 1 & 1 \\
\hline Are objective and unbiased results criteria used? & 1 & 1 & 1 & 1 \\
\hline Is the nicotine patch intervention measurement method validated? & 1 & 1 & 1 & 1 \\
\hline Is the effect size practically relevant? & 1 & 1 & 1 & 1 \\
\hline
\end{tabular}


Was there any conviction intervention provided?

Have you taken the confounding factor into account?

Do the results apply to your research?

Total

Answer: $1=$ Yes, $0=$ No

$\begin{array}{rrrr}1 & 1 & 1 & 1 \\ 1 & 1 & 1 & 1 \\ 1 & 1 & 1 & 1 \\ 11 & \mathbf{1 2} & \mathbf{1 2} & \mathbf{1 2}\end{array}$

Table 3. Descriptions of primary studies included in the meta-analysis

\begin{tabular}{|c|c|c|c|c|c|c|c|c|}
\hline $\begin{array}{c}\text { Author } \\
\text { (Year) }\end{array}$ & Title & Country & $\begin{array}{c}\text { Study } \\
\text { Design }\end{array}$ & Sample & $\begin{array}{c}\mathbf{P} \\
\text { Population } \\
\end{array}$ & $\begin{array}{c}\text { I } \\
\text { Intervention }\end{array}$ & $\begin{array}{c}\mathbf{C} \\
\text { Comparison } \\
\end{array}$ & $\begin{array}{c}\text { O } \\
\text { Outcome }\end{array}$ \\
\hline $\begin{array}{l}\text { Beard } \\
\text { et al. } \\
(2013)\end{array}$ & $\begin{array}{l}\text { Association between of nicotine } \\
\text { replacement therapy for ham } \\
\text { reduction and smoking cessation: } \\
\text { Study of English smoker. }\end{array}$ & UK & Cohort & 3,149 & $\begin{array}{l}\text { Adult smokers } \\
\text { age } \geq 18 \text { years }\end{array}$ & Patch Nicotine & Placebo & Quit smoking \\
\hline $\begin{array}{l}\text { Hollands } \\
\text { et al. } \\
(2013)\end{array}$ & $\begin{array}{l}\text { Adherence to and consumption of } \\
\text { nicotine replacement therapy and } \\
\text { the relationship with abstinence } \\
\text { within a smoking cessation trial in } \\
\text { primary care }\end{array}$ & UK & Cohort & 633 & $\begin{array}{l}\text { Adult Smokers } \\
\text { Age } \geq 18 \text { Years }\end{array}$ & Patch Nicotine & Placebo & Quit smoking \\
\hline $\begin{array}{l}\text { Japuntich } \\
\text { et al. } \\
\text { (2014) }\end{array}$ & $\begin{array}{l}\text { The effect of five smoking cessation } \\
\text { pharmacotherapies on smoking } \\
\text { cessation milestones }\end{array}$ & $\begin{array}{l}\text { United } \\
\text { States of } \\
\text { America }\end{array}$ & Cohort & 1,504 & $\begin{array}{l}\text { Adult Smokers } \\
\text { Age } \geq 18 \text { Years }\end{array}$ & Patch Nicotine & Placebo & Quit smoking \\
\hline $\begin{array}{l}\text { Lerman } \\
\text { et al. } \\
\text { (2015) }\end{array}$ & $\begin{array}{l}\text { Use of the nicotine metabolite ratio } \\
\text { as a genetically informed biomarker } \\
\text { of response to Nicotine patch or } \\
\text { Varenicline for smoking cessation: } \\
\text { A randomised, double-blind } \\
\text { placebo controlled trial }\end{array}$ & New York & Cohort & 1,246 & $\begin{array}{l}\text { Adult Smokers } \\
\text { Ages 18-65 Years }\end{array}$ & Patch Nicotine & Placebo & Quit smoking \\
\hline $\begin{array}{l}\text { Piper } \\
\text { et al. } \\
\text { (2011) }\end{array}$ & $\begin{array}{l}\text { Tobacco withdrawal components } \\
\text { and their relations with cessation } \\
\text { success }\end{array}$ & $\begin{array}{l}\text { United } \\
\text { States of } \\
\text { America }\end{array}$ & Cohort & 1,504 & $\begin{array}{l}\text { Adult Smokers } \\
\text { Age } \geq 18 \text { Years }\end{array}$ & Patch Nicotine & Placebo & Quit smoking \\
\hline $\begin{array}{l}\text { Anthenell } \\
\text { i et al. } \\
\text { (2016) }\end{array}$ & $\begin{array}{l}\text { Neuropsychiatric safety and efficacy } \\
\text { of Varenicline, Bupropion, and } \\
\text { Nicotine patch in smokers with and } \\
\text { without psychiatric disorders } \\
\text { (EAGLES) }\end{array}$ & $\begin{array}{l}\text { United } \\
\text { States of } \\
\text { America }\end{array}$ & Cohort & 4,028 & $\begin{array}{l}\text { Adult Smokers } \\
\text { Ages 18-75 Years }\end{array}$ & Patch Nicotine & Placebo & Quit smoking \\
\hline Thomas & Quitting experiences and & Australia & Cohort & 600 & Adult Smokers & Patch Nicotine & Placebo & Quit smoking \\
\hline
\end{tabular}




\begin{tabular}{|c|c|c|c|c|c|c|c|c|}
\hline $\begin{array}{l}\text { et al. } \\
(2014)\end{array}$ & $\begin{array}{l}\text { preferences for a future quit } \\
\text { attempt: A study among inpatient } \\
\text { smokers }\end{array}$ & & & & Age $\geq 18$ Years & & & \\
\hline $\begin{array}{l}\text { Kusnir } \\
\text { et al. } \\
(2017)\end{array}$ & $\begin{array}{l}\text { Mailed distribution of free nicotine } \\
\text { patches without behavioral support: } \\
\text { Predictors of use and cessation }\end{array}$ & Canada & Cohort & 421 & $\begin{array}{l}\text { Adult Smokers } \\
\text { Age } \geq 18 \text { Years }\end{array}$ & Patch Nicotine & Placebo & Quit smoking \\
\hline $\begin{array}{l}\text { West } \\
\text { et al. } \\
(2017)\end{array}$ & $\begin{array}{l}\text { Factors associated with the efficacy } \\
\text { of smoking cessation treatments } \\
\text { and predictors of smoking } \\
\text { abstinence in EAGLES }\end{array}$ & $\begin{array}{l}\text { United } \\
\text { States of } \\
\text { America }\end{array}$ & Cohort & 8,120 & $\begin{array}{l}\text { Adult Smokers } \\
\text { Ages 18-75 Years }\end{array}$ & Patch Nicotine & Placebo & Quit smoking \\
\hline
\end{tabular}

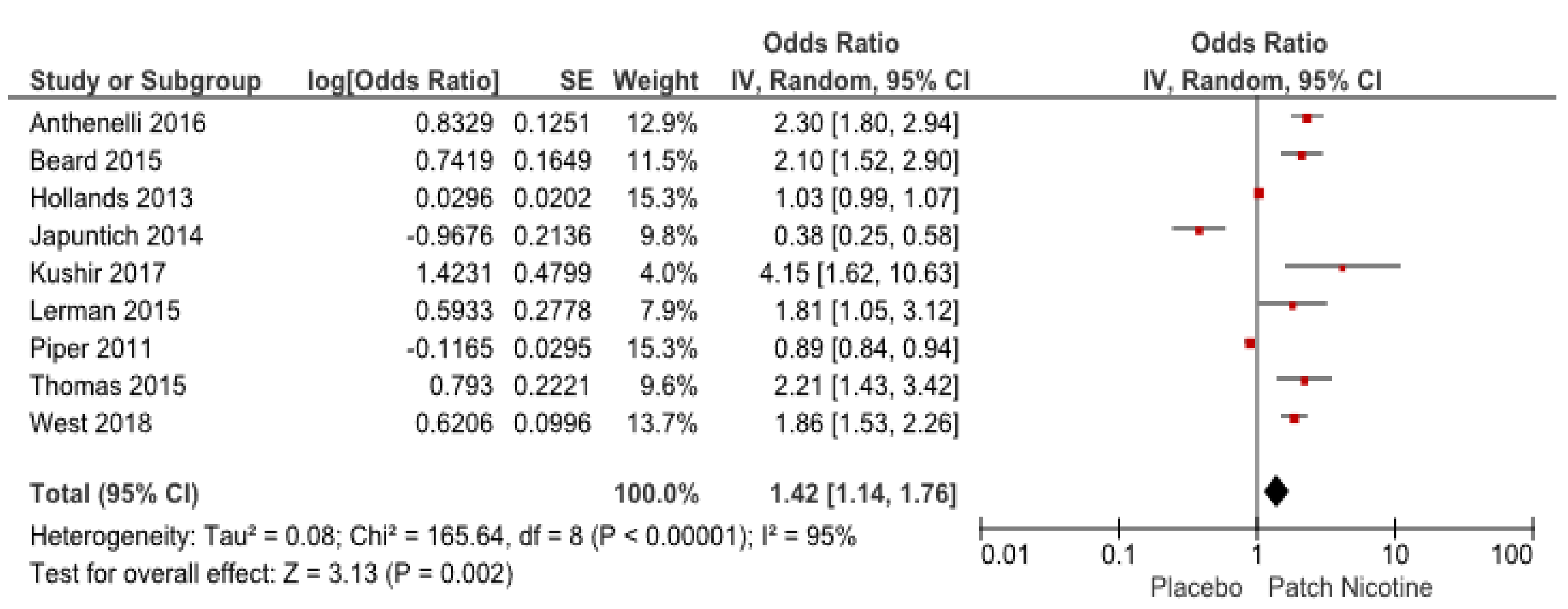

Figure 3. Forest Plot The Effect of Nicotine Replacement Therapy on the Success of Quitting Smoking 


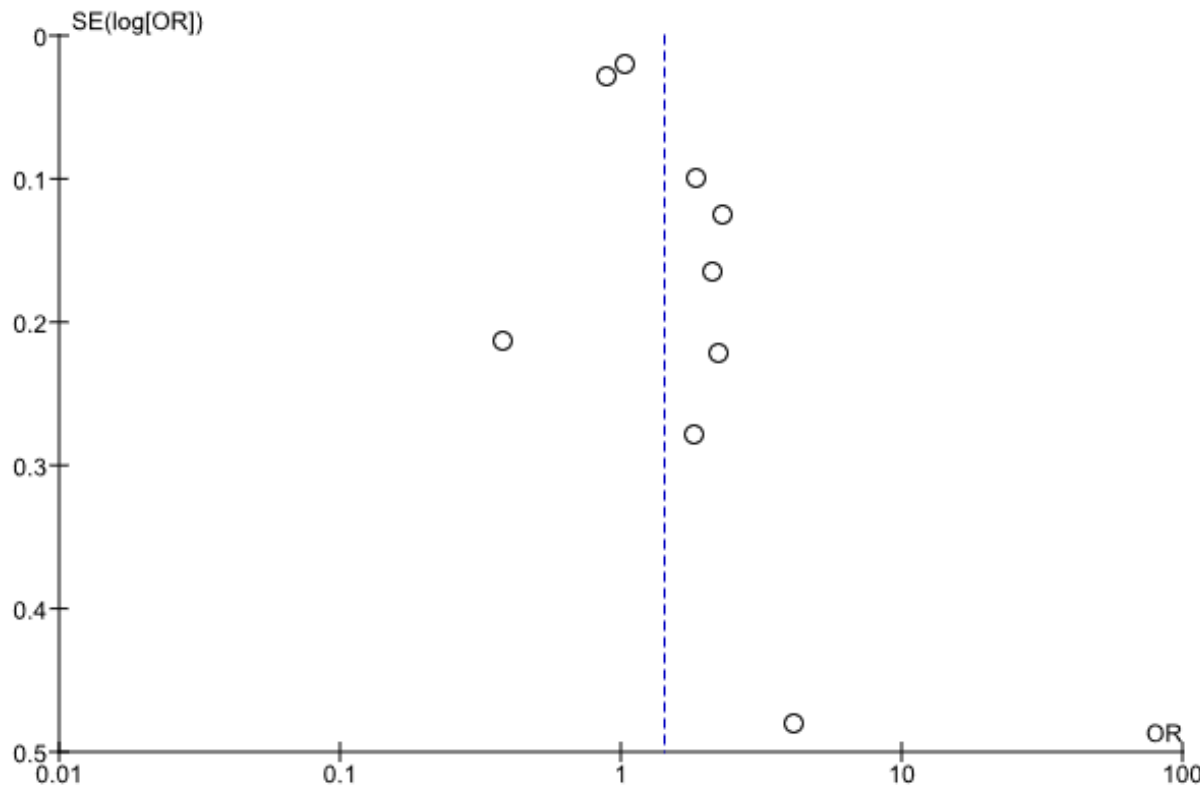

Figure 4. Funnel Plot of the Effect of Nicotine Replacement Therapy on the Success of Quitting Smoking

\section{DISCUSSION}

The results of the forest plot from the cohort study design research article showed that adult smokers who used NRT in the form of a nicotine patch increased smoking cessation success 1.42 times compared to adult smokers who did not use a placebo $(\mathrm{aOR}=1.42 ; 95 \% \mathrm{CI}=1.14$ to $1.76 ; \mathrm{p}=$ 0.002). The results of this study are supported by the results of study by Tulloch et al. (2016) at the Ottawa Heart Institute Canada who stated that flexible NRT and varenicline increased success in the early phase of smoking cessation. Multiple forms of nicotine replacement therapy can increase smoking cessation rates in the long run.

The results of the same study also in the study of Haddad et al. (2020) support this study by stating that the nicotine patch can significantly help smokers to quit smoking while abstaining from smoking for 12 months, but the results are more optimal if the combination NRT is used to quit smoking permanently.
Smoking behavior usually starts in childhood or adolescence. 80\% of smokers start smoking by the age of 18 , although $20 \%$ to $25 \%$ of them are casual smokers. Usually 65.66 times the risk factors for smoking in childhood or adolescence are influenced by peer influence, parents, behavioral problems, personality and genetics. So that smoking behavior becomes a habit until they are adults (Benowitz, 2010).

NRT is the first recognized regimen for treating nicotine dependence and remains the first-line therapy to date. NRT can overcome withdrawal symptoms and reduce cravings for smoking by restoring nicotine saturation at $\alpha_{4} \beta 2$ receptors and thereby keeping dopamine levels in Naku stable. The bioavailability of NRT is lower than that of nicotine from cigarettes, due to limited absorption when NRT is inhaled through the lungs (Supit 2016).

The nicotine inhaled from cigarette smoke is easily absorbed in the large surface area of the lungs and transported directly to the brain via the pulmonary venous system in 10-20 seconds. The level 
of nicotine that reaches the brain drops rapidly as nicotine is redistributed back into the body, mostly to the skeletal muscles.

Nicotine replacement therapy from chewing gum, lozenges, inhalers and nasal sprays is absorbed through the oral or nasal mucosa and enters the sympathetic venous circulation. These forms cause nicotine levels to peak within minutes, while the nicotine patch releases nicotine more gradually at peak concentrations within a few hours of use. Ingested nicotine can worsen the acidic environment of the stomach and some of it is absorbed in the small intestine and carried to the portal venous circulation where it undergoes firstpass hepatic metabolism, resulting in low bioavailability (30\%-40\%) therefore nicotine therapy through this process is not recommended. Nicotine replacement therapy helps stop smoking by stabilizing the levels of nicotine in the blood, thereby reducing the positive and negative reinforcing effects of faster-acting nicotine delivery mechanisms such as cigarettes (Flowers, 2017).

Use of nicotine replacement therapy has common side effects including headache, nausea, vomiting, stomach upset and diarrhea. Nicotine replacement therapy is relatively safe to use in the normal population and is not associated with an increased risk of cardiovascular adverse events in the first year after acute coronary syndrome (Woolf, 2012).

The United States is the country with the most research locations, namely six articles where in the United States nicotine replacement therapy products in the form of nicotine patches, sprays and chewing gum can be used by the public without using a doctor's prescription. This is because nicotine replacement therapy is given to replace nicotine, reduce symptoms of relapse, and stop smoking (Limsuwan, 2018).

In Indonesia, Nicotine replacement therapy products are sold freely in the form of chewing gum, nasal sprays, inhalers, sublingual tablets and nicotine patches (Supit 2016).

Indonesia is a country with a fairly high level of cigarette consumption, according to research by Putri et al. (2017) knowledge of adolescents in Surabaya regarding smoking is high, while knowledge of NRT is categorized as moderate. Based on this, it is necessary to educate on the use of NRT. This is important because NRT is a therapeutic option that has the opportunity to be applied in the treatment of cigarette addiction among smokers. The goal is that the number of Indonesian smokers can decrease. Thus, the demographic bonus for Indonesia which is expected to occur in 2035 will be able to produce healthy and quality human resources (Putri, 2017).

\section{AUTHOR CONTRIBUTION}

Lina Eta Safitri is the principal researcher who selects topics, searches and collects research data. Agus Kristiyanto and Bhisma Murti played a role in analyzing data and reviewing research documents.

\section{CONFLICT OF INTEREST}

There is no conflict of interest in this study.

FUNDING AND SPONSORSHIP

This study is self-funded.

\section{ACKNOWLEDGEMENT}

We are very grateful to the database providers Google Scholar, PubMed, Science Direct, and SCI-HUB.

\section{REFERENCE}

Adam NT, Marris J (2020). Smoking. StatPearls. https://www.ncbi.nlm.nih.- 
Safitri et al./ Nicotine Replacement Therapy on the Successful Smoking Cessation

gov/books/NBK430685 in Februari 2021.

Arifianti T, Soemanto, Prasetya H (2019). The contextual effect of school on smoking behavior among male high school students. J Health Promot Behav. 4(1): 76-84. doi.org/10.26911/thejhpb. 2019.04.01.08.

Arifin J, Mccracken LC, Nesbitt A, Warner A, Dinniwell RE, Palma DA, Louie AV (2020). Does free nicotine replacement improve smoking cessation rates in cancer patients. Curr Oncol. 27(1): 14-18. DOI:10.3747/co.27.5267.

Benowitz NL (2010). Nicotine Addiction. N Engl J Med. 362(24): 2295-303. https://doi.org/10.1056/nejmrao8o 9890.

Brainly (2018). Batas-Batas Letak Geografis Australia. Accessed from https://brainly.co.id/tugas/26111958 in May 2021.

Cather C, Pachas GN, Cieslak KM, Evins AE, (2017). Achieving smoking cessation in individuals with schizophrenia: Special considerations. CNS Drug. 31(6). 471-481. https://doi.org/10.1007/s40263-017-04388.

Cochrane (2014). RevMan 5.3 User Guide. https://training.cochrane.org/sites/ training.cochrane.org/files/public/u ploads/resources/downloadable_res ources/English/RevMan_5.3_User_ Guide.pdf.

Edgwick P (2013). Meta-analyses: How to read a funnel plot. In BMJ. 346 (7898). http://doi.org/10.1007/bmj.f1342.

Edunitas (2019). North America. Accessed from http://kk.sttbandung.ac.id/id1/1-3060-2940/Amerika-Utara_12180_ensiklopedia-bebas-q-sttbandung.html in May 2021.
Flowers L (2017). Nicotine Replacement Therapy. Am J Psychiatry Resid J. 11(6): 4-7. Doi.org/10.1176/appi.ajprj.2016.110602.

Graham AL, Papandonatos GD, Cha S, Erar B, Amato MS (2018). Improving adherence to smoking cessation treatment: Smoking outcomes in a web-based randomized trial. Ann Behav Med. 52(4): 331341. https://doi.org/10.1093/ntr/ntw282.

Haaker H, Lonsdorf TB, Schumann D, Bunzeck N, Peters J, Sommer T, Kalisch $R$ (2017). Where there is smoke there is fear-impaired contextual inhibition of conditioned fear in smokers. Int $\mathrm{J}$ Neuropsychopharmacology. 42(8): 1640-1646. https://doi.org/10.1038/npp.2017.17.

Haddad I, Samman A, Person T, Karakattu S, Mehta J (2020). Combined nicotine replacement therapy (Nicotine patch and short acting nicotine) VS nicotine patch for smoking cessation: A systematic review and metaanalisis. J. Chest. 158(4): 18-21. https://doi.org/10.1016/j.chest.202 0.08.2014.

Islami SU, Prasetya H, Murti B (2019). Schools have contextual influence on smoking behavior among high school students in Dumai, Riau. J Health Promot Behav. 4(3): 212223. doi.org/10.26911/thejhpb.2019.04.03.06.

Kementerian Kesehatan Republik Indonesia. (2017). Hidup sehat tanpa rokok (Healthy living without smoking). Kementerian Kesehatan Indonesia.

Kementerian Kesehatan Republik Indonesia (2019). HTTS 2019: Jangan biarkan rokok merenggut napas kita (HTTS 2019: don't let cigarettes take our breath). Accessed from https://www.kemenkes.go.id/article/view/- 
Safitri et al./ Nicotine Replacement Therapy on the Successful Smoking Cessation

19071100001/htts2019janganbiarka nrokok-merenggutnapas-kita.html in February 2021.

Krus GR, Park E, Haberer L, Abroms, Shadid NN, Howard, Chang Y (2019). Proactive text messaging (GetReady2Quit) and nicotine replacement therapy to promote smoking cessation among smokers in primary care: A pilot randomized trial protocol. Contemp Clin Trials. 80: 48-54. https://doi.org/10.1016/j.cct.2019.0 3.006.

Krus G, Park ER, Shahid NN, Abroms L, Haberer JE, Rigotti NA (2019). Combining real-time ratings with qualitative interviews to develop a smoking cessation text messaging program for primary care patients. JMIR Mhealth Uhealth. 7(3): e11498. https://doi.org/10.2196/11498.

Kumparan (2021). Karakteristik benua Eropa yang membedakannya dari wilayah lainnya (The characteristics of the European continent that set it apart from other regions). Accessed from https://kumparan.com/beritahari-ini/karakteristik-benua-eropayang-membedakannya-dari-wilayah-lainnya-1u4TFseLDxk/full in May 2021.

Lappin JM, Thomas D, Curtis J, Blowfield S, Gasti M, Marr G, Courtney R (2020). Targeted intervention to reduce smoking among people with severe mental illness: Implementation of a smoking cessation intervention in an inpatient mental health setting. Medicina (Kaunas). 56(4): 204. https://doi.org/10.3390/medicina56040204.

Limsuwat C, Saito S, Halvorso K (2018). Review: Pharmacotherapy for smoking cessation. The Southwest Respiratory and Critical Care Chro- nicles. 6(24). 31-37. https://doi.org/10.12746/swrccc.v6i25.482.

Linda R, Gowing, Robert L, Ali1, Allsop S, Marsden J, Turf E (2015). Global statistics on addictive behaviours: 2014 status report. Addiction. 110 (6):904-19. https://doi.org/10.1111/add.12899.

Martin LM, Sayette MA (2018). A review of the effects of nicotine on social functioning. Exp Clin Psyhopharmacol. 26(5): 425-439. https://doi.org/10.1037/phaoooo208.

Metse AP, Wiggers J, Wye P, Bowman JA, (2018). Patient receipt of smoking cessation care in four Australian Acute psychiatric facilities. $\mathrm{J}$ Ment Health Nurs. 27(5). 1556-1563. doi: 10.1111/inm.12459.

Mikolajewicz N, Komarova SV (2019). Meta-analytic methodology for basic research: A practical guide. Front Physiol. 10: 203. https://doi.org/10.3389/fphys.2019.00203.

Nikolakopoulou A, Chaimani A, Veroniki AA, Vasiliadis HS, Schmid $\mathrm{CH}$, Salanti G (2014). Characteristics of networks of interventions: A description of a database of 186 published networks. PLoS ONE, 9(1): e86754. https://doi.org/10.1371/journal.pone.0086754.

Nightingale CL, Sterba KR, Tooze JA, King JL, Weaver KE (2019). Cessation attitudes and preferences in head and neck cancer patients and implycations for cessation program design: A brief report. Glob Adv Health Med. 8: 2164956119847117. https://doi.org/10.1177/2164956119 847117.

Rajani NB, Weth, Mastellos N, filippidis FT (2019). Adherence of popular smoking cessation mobile applications to evidence-based guidelines. BMC 
Safitri et al./ Nicotine Replacement Therapy on the Successful Smoking Cessation

Public Health. 19(1): 743. https://doi.org/10.1186/s12889-019-7084-7.

Ramdhani N (2011). Penyusunan alat pengukuran berbasis Theory of Planned Behavior (Development of measurement tools based on Theory of Planned Behavior). Buletin Psikologi. 19 (2): 55-69. https://doi.org/10.22146/bpsi.11557.

Schuit E, Panagiotou OA, Munafo MR, Bennett DA, Bergen AW, David SP (2017). Pharmacotherapy for smoking cessation: Effects by subgroup defined by genetically informed biomarkers. Cochrane Library. 9(9): CDo11823. https://doi.org/10.1002/14651858.cd 011823.pub2.

Setyawati A (2013). Suatu kajian molekuler ketergantungan nikotin (A molecular study of nicotine dependence). $\mathrm{J}$ Pharm Sci community. 10(2):118-127. https://doi.org/10.24071/jpsc.0098.

Sukmana $T$ (2011). Mengenal rokok dan bahayanya (Knowing about smoking and its dangers). Jakarta: Be Champion.

Supit (2016). Ketergantungan Nikotin: asap molekuler dan implikasi terapi berbasis bukti (Nicotine dependence: molecular smoke and implications of evidence-based therapy). Cermin Dunia Kedokteran. 43(4).

Torres S, Samino S, Ràfols P, Green MM, Correig X, Ramírez N (2020). Unravelling the metabolic alterations of liver damage induced by thirdhand smoke. Environ Int. 146: 106242. https://doi.org/10.1016/j.envint.2020 .106242.

Tulloch HE, Pipe A, Els C, Clyde MJ, Reid RD (2016). Flexible, dual-form nicotine replacement therapy or vareni- cline in comparison with nicotine patch for smoking cessation randomized controlled trial. BMC Med. 14(80): 2-10. https://doi.org/10.1186/s12916-016-0626-2.

Oakes JM, Fuchs RM, Gardner JD, Lazartigues E, Yue $X$ (2018). Nicotine and the renin-angiotensin system. Am J Physiol Regul Integr Comp physiol. 315 (5). 895-906. https://dx.doi.org/10.1152\%2Fajpregu.00099.2018.

Putri AK, Zuhroh LZ, Ashari A, Sakinah A, Permatasari DA, Kodisu AE, Putri DA, et al. (2017) Perilaku merokok dan pengtahuan tentang nicotine replacement Therapy pada remaja (Smoking behavior and knowledge about Nicotine Replacement Therapy in Adolescents). Jurnal Farmasi Komunitas. 4(1): 127-132. https://journal.unair.ac.id/download-fullpapers-jfkc34229bd842full.pdf.

Wadgave U, Nagesh L (2020). Nicotine replacement therapy: An overview. Int J Med sci Public Health. 10(3): 425-435. https://www.ncbi.nlm.nih.gov/pubmed/27610066.

World Health Organization (2020). Pernyataan WHO: Penggunaan Tembakau dan COVID-19 (WHO statement: Tobacco Use and COVID-19). Accessed from www.who.int/indonesia/new/detail/11-05-2020-pernyataan-whopenggunaan-tembakau-dan-covid-19. in Februari 2021.

Woolf JK, Zabad MN, Post JM, McNitt S, Williams GC, Bisognano JD (2012). Effect of nicotine replacement therapy on cardiovascular outcomes after acute coronary syndromes. Am J cardiol. 110 (7). 168-170. https://doi.org/10.1016/j.amjcard.2012.05.028. 